\title{
Early Holocene ritual complexity in South America: the archaeological record of Lapa do Santo (east-central Brazil)
}

André Strauss ${ }^{1,2,3,4, *}$, Rodrigo Elias Oliveira ${ }^{3,5}$, Ximena S. Villagran ${ }^{6}$, Danilo V. Bernardo ${ }^{7}$, Domingo C. Salazar-García ${ }^{1,8,9,10}$, Marcos César Bissaro Jr ${ }^{11}$, Francisco Pugliese ${ }^{6}$, Tiago Hermenegildo ${ }^{12}$, Rafael Santos ${ }^{13}$, Alberto Barioni ${ }^{3,14}$, Emiliano Castro de Oliveira ${ }^{3,15}$, João Carlos Moreno de Sousa ${ }^{16}$, Klervia Jaouen ${ }^{1}$, Max Ernani ${ }^{3}$, Mark Hubbe ${ }^{17,18}$, Mariana Inglez ${ }^{3}$, Marina Gratão ${ }^{3}, \mathrm{H}$. Rockwell ${ }^{19}$, Márcia Machado ${ }^{20}$, Gustavo de Souza ${ }^{21}$, Farid Chemale ${ }^{22}$, Koji Kawashita ${ }^{23}$, Tamsin C. O'Connell ${ }^{12}$, Isabel Israde ${ }^{24}$, James Feathers ${ }^{25}$, Claudio Campi ${ }^{26}$, Michael Richards ${ }^{1}$, Joachim Wahl ${ }^{2,27}$, Renato Kipnis ${ }^{3}$, Astolfo Araujo ${ }^{6} \&$ Walter Neves $^{3}$

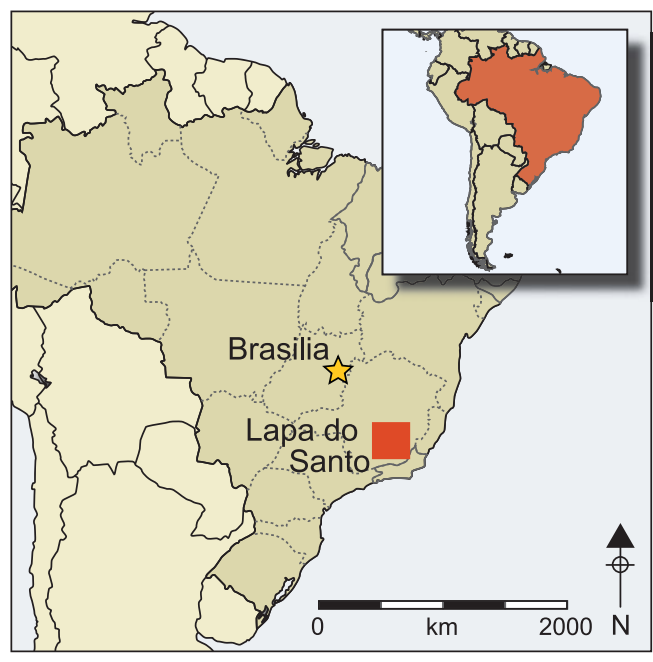

Early Archaic human skeletal remains found in a burial context in Lapa do Santo in eastcentral Brazil provide a rare glimpse into the lives of hunter-gatherer communities in South America, including their rituals for dealing with the dead. These included the reduction of the body by means of mutilation, defleshing, tooth removal, exposure to fire and possibly cannibalism, followed by the secondary burial of the remains according to strict rules. In a later period, pits were filled with disarticulated bones of a single individual without signs of body manipulation, demonstrating that the region was inhabited by dynamic groups in constant transformation over a period of centuries.

Keywords: Brazil, Lagoa Santa, Lapa do Santo, early Archaic period, Palaeoindian, mortuary rituals 


\section{Introduction}

In reconstructing the life of past populations, human burials are highly informative of symbolic and ritual behaviour. In many societies, bones and body parts constituted a potent cultural resource, and their manipulation and organisation into meaningful arrangements was commonly used to reify cosmological ideas and belief systems (Goldstein 2000; Brown 2010). This kind of practice is usually considered to be part of a broader system of

1 Department of Human Evolution, Max Planck Institute for Evolutionary Anthropology, Deutscher Platz 6, 04103 Leipzig, Germany

2 Palaeoanthropology Senckenberg Centre for Human Evolution and Palaeoenvironment, Eberhard Karls Universität Tübingen, Rumelinstrasse 23, 72074 Tübingen, Germany

3 Departamento de Genética e Biologia Evolutiva, Universidade de São Paulo, Rua do Matão 277, São Paulo, SP, Brazil

4 Centro de Arqueologia Annette Laming Emperaire, Av. Acdo. Nilo Figueiredo 2, Lagoa Santa, MG, Brazil

5 Departamento de Estomatologia, Faculdade de Odontologia, Universidade de São Paulo, Av. Professor Lineu Prestes 2227, São Paulo, SP, Brazil

6 Museu de Arqueologia e Etnologia, Universidade de São Paulo, Av. Prof. Almeida Prado 1466, Butantã, São Paulo, SP, Brazil

7 Instituto de Ciências Humanas e da Informação, Universidade Federal do Rio Grande, Av. Itália KM 8, Carreiros, Rio Grande, RS, Brazil

8 Department of Archaeology, University of Cape Town, Private Bag X3, Rondebosch 7701, South Africa

9 Department of Archaeogenetics, Max Planck Institute for the Science of Human History, Kablaische Strasse 10, 07745 Jena, Germany

10 Departament de Prehistòria i Arqueologia, Universitat de Valencia, Av. Blasco Ibáñez 28, 46010 Valencia, Spain

11 Faculdade de Filosofia, Ciências e Letras de Ribeirão Preto, Universidade de São Paulo, Av. Bandeirantes 3900 , Vila Monte Alegre, Ribeirão Preto, SP, Brazil

12 Department of Archaeology and Anthropology, University of Cambridge, Downing Street, Cambridge CB2 3DZ, $U K$

13 Fundação Nacional do Índio, Coordenação Regional Xavante, Barra do Garças, MT, Brazil

14 Departamento de História e Geografia, Universidade de São Paulo, Av. Prof. Lineu Prestes 338, Butantã, São Paulo, SP, Brazil

15 Departamento de Ciências do Mar, Universidade Federal de São Paulo, Campus Baixada Santista, Santos, Brazil

16 Museu Nacional, Universidade Federal do Rio de Janeiro, Quinta da Boa Vista, Rio de Janeiro, RJ, Brazil

17 Department of Anthropology, The Ohio State University, $174 \mathrm{~W} .18^{\text {th }}$ Avenue, Columbus, OH 43210, USA

18 Instituto de Arqueología y Antropología, Universidad Católica del Norte, Gustavo Le Paige 380, San Pedro de Atacama, Chile

19 Department of Anthropology, University of Wyoming, 1000 E. University Avenue, Laramie, WY 82071, USA

20 Laboratório de Design e Seleção de Materiais, Universidade Federal do Rio Grande do Sul, Av. Osvaldo Aranha 99, Porto Alegre, RS, Brazil

21 Instituto do Patrimônio Histórico e Artístico Nacional - IPHAN, Superintendência de Minas Gerais, Belo Horizonte, $M G$, Brazil

22 Instituto de Geociências, Universidade Federal de Minas Gerais, Av. Antônio Carlos 6.627, Pampulha, Belo Horizonte, $M G$, Brazil

23 Instituto de Geociências, Universidade de Brasília, Darcy Ribeiro ICC, Ala Central, Brasilia, Brazil

24 Instituto de Investigaciones de Ciencias de la Tierra, Universidade Michoacana de San Nicolás de Hidalgo, Avenida Universidad 1471, Fraccionamiento Real Universidad, Morelia, Mexico

25 Department of Anthropology, University of Washington, 4218 Memorial Way Northeast, Seattle, WA 98105, USA

26 Departamento de Radiologia, Faculdade de Medicina, Universidade de São Paulo, Av. Dr. Arnaldo 455, Cirqueira César, São Paulo, SP, Brazil

27 Landesamt für Denkmalpflege, Regierungspräsidium Stuttgart, Osteologie, Stromeyersdorfstrasse 3, 78467 Konstanz, Germany

* Author for correspondence (Email: andre_strauss@eva.mpg.de)

(C) Antiquity Publications Ltd, 2016 
ceremonies that reflect a high degree of symbolic complexity, and is therefore of great interest for archaeologists worldwide (Sofaer 2006).

In South America, despite recent studies revisiting the possibility of occupations in the continent going back 28000 years or more (Boëda et al. 2014), human skeletal remains only appear in the archaeological record from the early Holocene (Bueno et al. 2013). In this early Archaic period, most landscapes of the sub-continent were already occupied and human populations thrived (see Araujo et al. 2012 for a synthesis). These groups are relatively well studied with regard to their mobility patterns and subsistence strategies, being characterised as generalist foragers with a strong emphasis on the exploitation of vegetable and aquatic items when available. Information relating to ideational, symbolic or ritualistic aspects is, however, limited. One source, rock art, is difficult to date with precision, and most of the information on symbolic behaviour during the early Holocene is derived from the analysis of human burials (Araujo et al. 2012).

In the western portion of the continent, substantial efforts have been made both to increase the number of available sites and to provide new theoretical frameworks (Santoro et al. 2005). In a synthesis of the available evidence on the Andean region, Santoro and collaborators (2005: 330) conclude that "the manipulation and transformation of dead bodies was more common than previously thought in the study of Archaic mortuary rituals". Despite considerable diversity of mortuary practices, a common emphasis on the preservation or reduction of the body can already be discerned during the early Archaic.

In the east, however, archaeological sites containing early Archaic skeletal remains are extremely rare, precluding the proper study of their ritual dimensions. One exception is the region of Lagoa Santa in central Brazil where hundreds of early Holocene human skeletons have been exhumed over almost two centuries of research. According to the classic descriptions, the mortuary practices in Lagoa Santa were simple and homogeneous, including only primary interments without grave goods (see online supplementary material (SI) for details), in contrast to the elaborate burials described for the western part of South America during the same period (Santoro et al. 2005).

In 2001, excavations restarted in Lagoa Santa, and findings from Lapa das Boleiras and Lapa do Santo engendered a transformation in our understanding of the mortuary rituals in the region (Araujo et al. 2012; Strauss et al. 2015). The abundance of well-preserved early Holocene burials at these sites offered a rare window onto the typically inaccessible world of the funerary rituals of the early Archaic hunter-gatherers in eastern South America (Araujo et al. 2012). Here, we report burials from Lapa do Santo and their associated archaeological context, and discuss their implication for a proper understanding of the mortuary landscape of South America during the early Holocene. Far from being simple, the burials of Lapa do Santo suggest an unexpected level of sophistication, with the manipulation and reduction of the fresh corpse being a key element of the rituals.

\section{Lapa do Santo: archaeological context}

Lapa do Santo is an archaeological site located in the northern part of the Lagoa Santa karst (Araujo et al. 2012; see SI-1 for details). Lagoa Santa, in east-central Brazil (Figure 1a), has been well known to archaeologists and palaeontologists since the nineteenth century,

(C) Antiquity Publications Ltd, 2016 

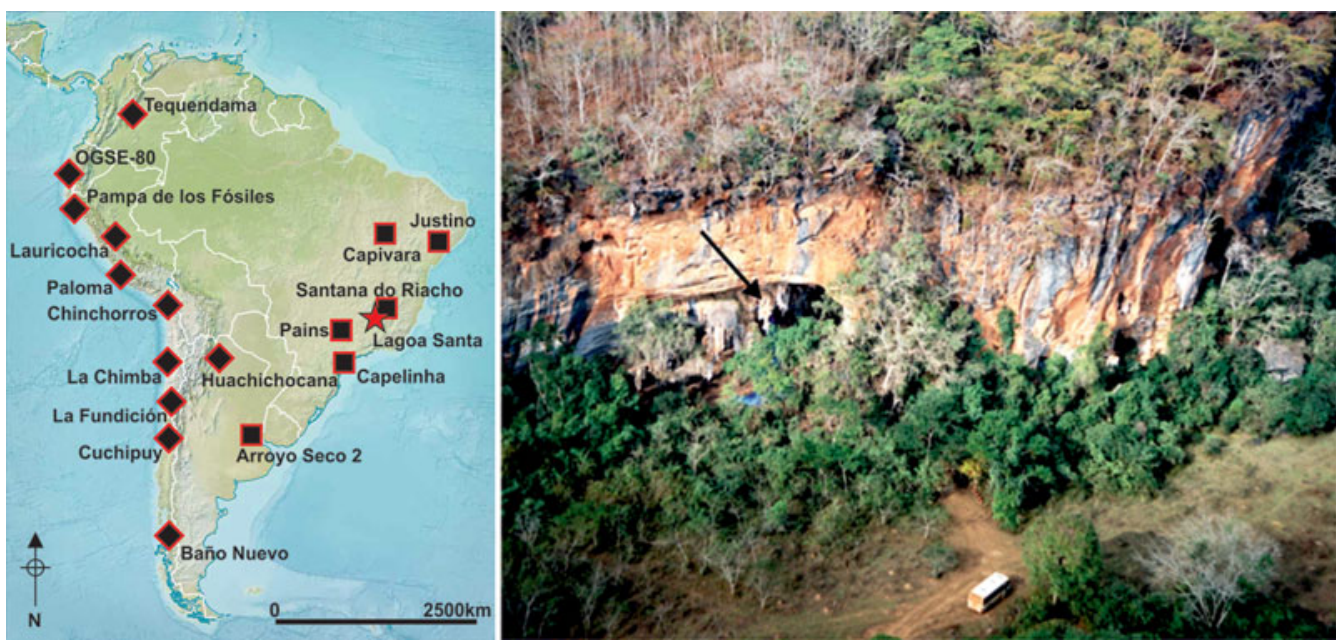

Figure 1. Left) map showing the Lagoa Santa region (red star) and other sites mentioned in the text (diamonds and squares). See SI-15 for detailed legend. Right) aerial view of the Lapa do Santo massif. The black arrow indicates the archaeological site.

when human skeletons were found in the Sumidouro Cave, associated with bones of extinct megafauna (see SI-1 for details). This putative coexistence of man and megafauna made Lagoa Santa the focus of many nineteenth- and twentieth-century scholars seeking evidence to confirm the coexistence hypothesis. Over more than 170 years of excavations, a large collection of early Holocene skeletons was formed (Da-Gloria 2012), but these early finds lack contextual information. The project 'Origins and Microevolution of Man in America: a Paleoanthropological Approach' aimed to address this by identifying and excavating new sites in the Lagoa Santa region.

The Lapa do Santo site is a cave with an associated sheltered area of around $1300 \mathrm{~m}^{2}$ (Figure $2 \mathrm{a}$ ) beneath the slope of a $30 \mathrm{~m}$-high limestone massif (Figure $1 \mathrm{~b}$ ). The southern part of the shelter, immediately in front of the cave entrance, is relatively flat, high and dry. The floor of the shelter slopes downwards towards the north, then becomes flat again near a natural sinkhole at the northern edge (Figure 2c-f). The chronology of the site is based on OSL (Tables S1-S5) and radiocarbon dating (Figure 3a, SI-2 \& Table S6) and defines three distinct periods of human occupation, the oldest starting at 11.7-12.7 ky cal BP (all chronological ranges are based on a 95.4\% interval; see Table S7). When the three periods are considered, there is good agreement between depth (i.e. z-value) and dated charcoals, showing the stratigraphic integrity of the deposits (Figure 3b). Site formation process analysis concluded that Lapa do Santo contains an expressive component of anthropogenic sediments produced after repeated combustion activities (Figure 4, SI-3 \& SI-4; Villagran et al. in press).

Zooarchaeological analysis indicates the presence of fish, lizards, rodents, armadillos, peccaries and deer that were brought in single pieces from the killing site (Bissaro 2008; Tables S8-S10, Spearman rho for \%MAU vs FUI $[\mathrm{n}=25]=0.34 ; p=0.09$; see SI-5). Carbon and nitrogen stable isotope analysis show slightly elevated $\delta^{13} \mathrm{C}$ and low $\delta^{15} \mathrm{~N}$ values in the adult population. Nitrogen isotope values are distinct from those for carnivores

(C) Antiquity Publications Ltd, 2016 

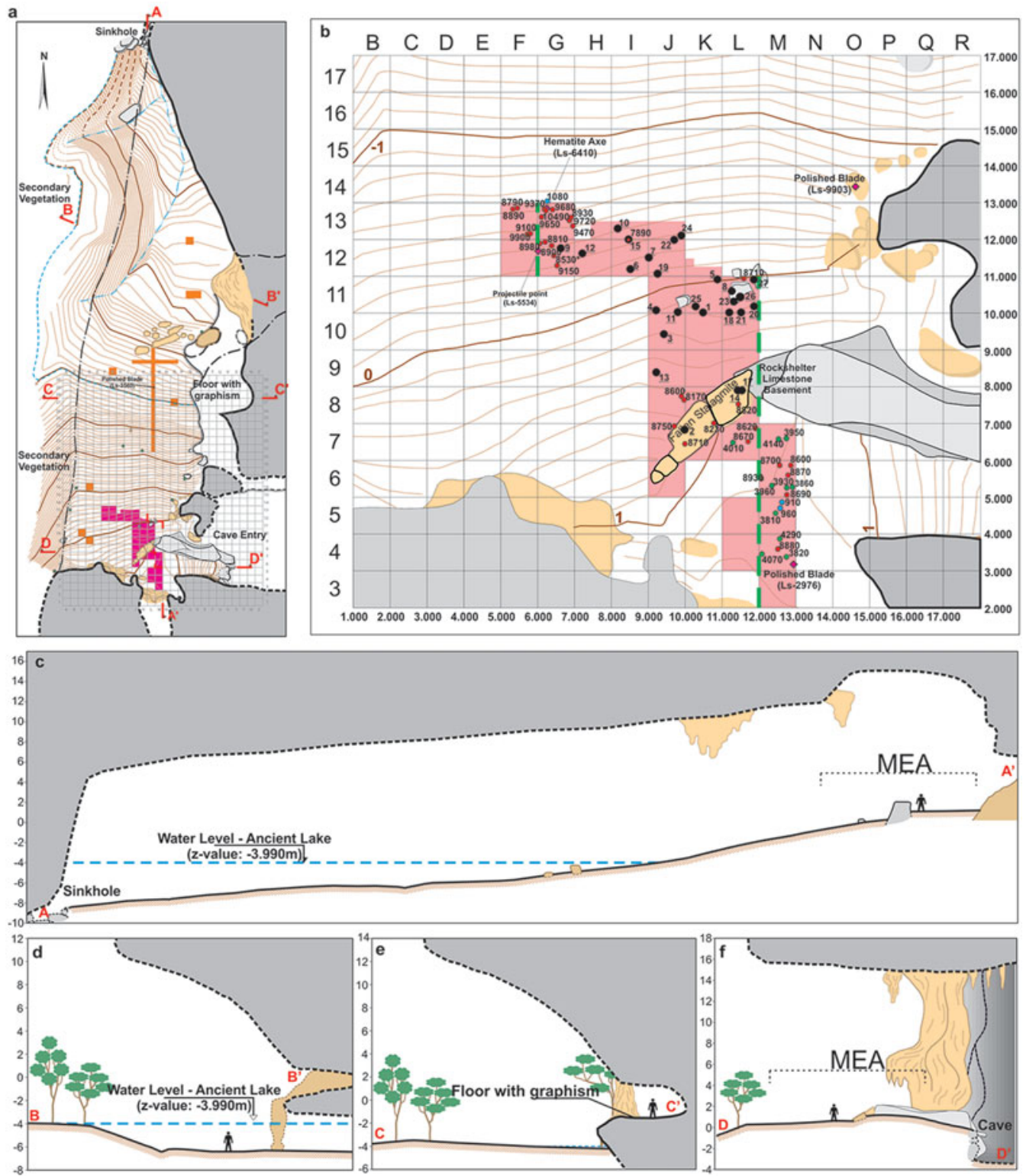

Figure 2. Plan of Lapa do Santo with the location of human burials and dated charcoals. Excavated area highlighted in light red.

$(t=4.50 ; p=0.001)$ and similar to those of herbivores from Lagoa Santa region $(t=0.25$; $p=0.400$ ), suggesting a heavy reliance on $\mathrm{C}_{3}$ plant resources (Figure 5, SI-6 \& Tables S11-S12). Together with frequencies of dental caries comparable to those of agricultural populations (Da-Gloria 2012), the emerging picture is of a typical early Archaic economy structured around plant resources that were probably rich in carbohydrates, complemented by the hunting of small and mid-sized animals.

(c) Antiquity Publications Ltd, 2016 

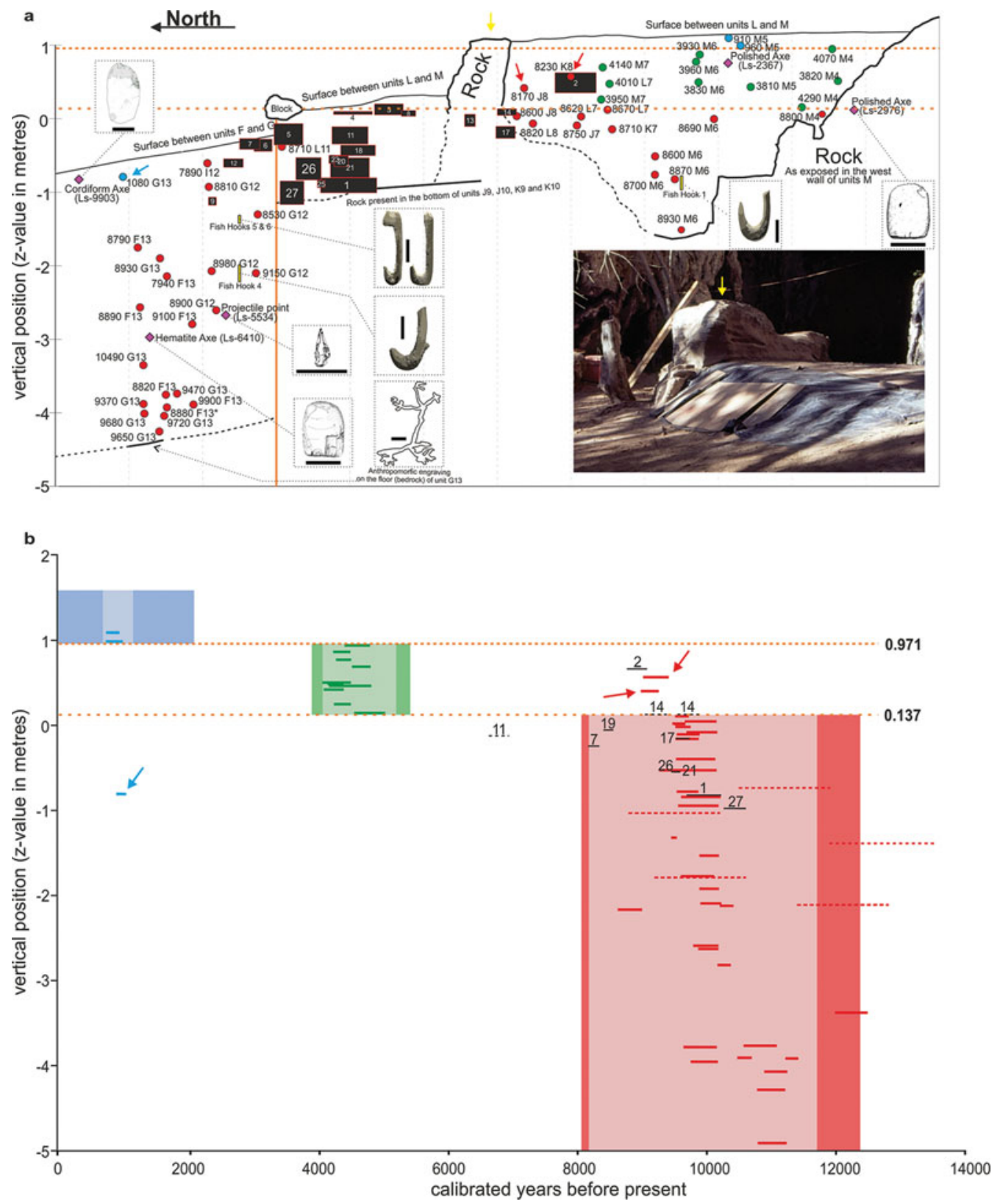

Figure 3. Chronology of Lapa do Santo: a) profile showing spatial distribution of dated samples and selected elements; b) scatterplot showing the relationship between vertical position (z-value) and age for different components of Lapa do Santo. See SI-15 for detailed legend.

The lithic assemblage is dominated by small flakes and cores (Pugliese 2007; SI-7 \& Figure S1). Crystal quartz was by far the dominant raw material, but silex, quartzite and silicified sandstone were also present. There is no clear division between artefacts and debitage in an industry where every flake was a potential tool. With the exception of a

(C) Antiquity Publications Ltd, 2016 

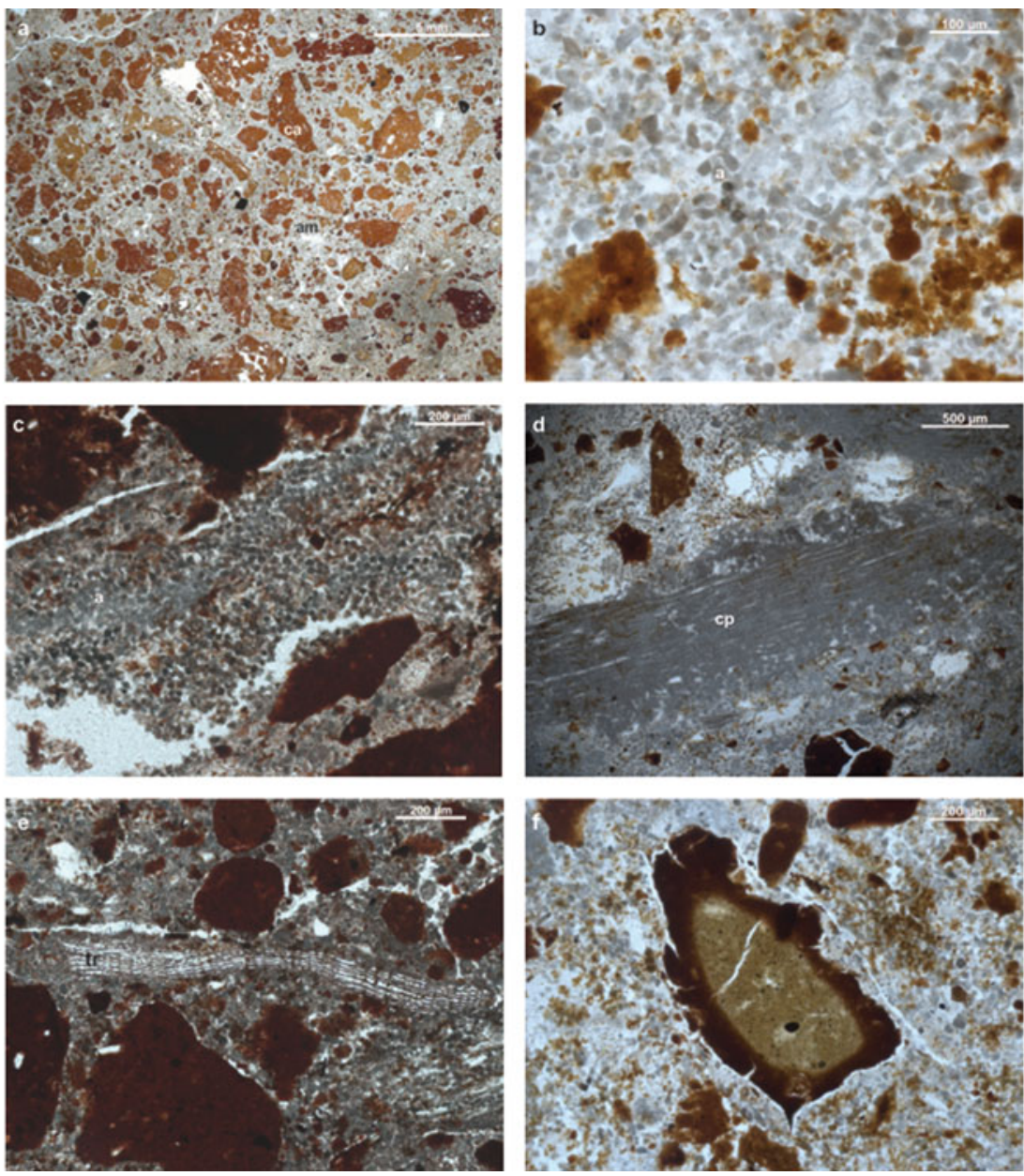

Figure 4. Photomicrographs of thin sections from Lapa do Santo, showing ash crystals and heated clay. See SI-15 for detailed legend.

single haematite axe blade (Table S13 \& Figure S2) and an arrow point (Figure S3), formal stone artefacts are not present in the early Holocene deposits. Flakes were discarded when their edges became dull, and most were used only a few times. Feather scars and occasional snap fractures were identified by preliminary use-wear analysis of flakes from Lapa do Santo, indicating that they were used to cut soft materials such as hides, meat, cordage and grasses (SI-8, Table S15 \& Figure S6). While lithic types were constant over time, the use of raw materials varied, and around $9.9 \pm 0.5 \mathrm{ky}$ cal BP, the exploitation of non-local sources such as silexite was drastically reduced, with the locally available crystal quartz becoming dominant (Pugliese 2007; Figure 6).

The bone artefacts from Lapa do Santo are very similar to those from other parts of central Brazil for the same time frame. They contrast sharply with the expedient technological approach adopted for the production of lithic artefacts. A total of 198 bone (C) Antiquity Publications Ltd, 2016 


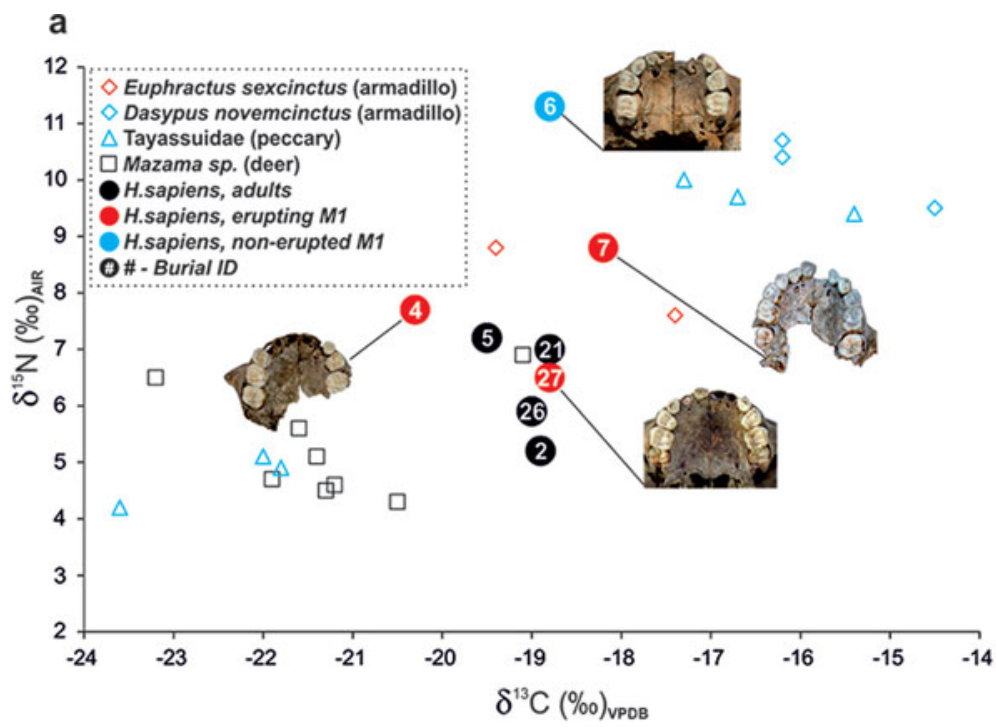

b

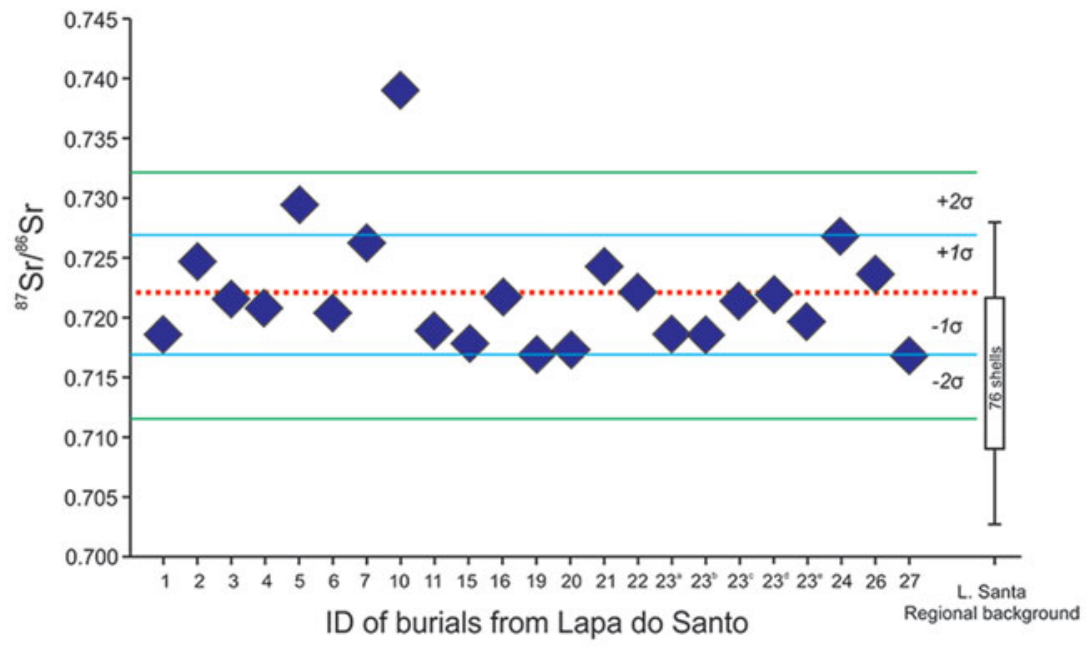

Figure 5. Isotopes analyses: a) $\delta^{15} N$ and $\delta^{13} C$ values of bone collagen from humans and animals from the Lagoa Santa region; b) enamel ${ }^{87} \mathrm{Sr}{ }^{86} \mathrm{Sr}$ ratio values from the individuals of Lapa do Santo, plotted on ${ }^{87} \mathrm{Sr} /{ }^{86} \mathrm{Sr}$ mean ratio value (red dashed line). See SI-15 for detailed legend.

artefacts or fragments were found, including spatulas (71\%), burins (25\%) and fishhooks (0.01\%) (SI-7, Table S14 \& Figures S4-S5).

Human enamel strontium isotopic values are close to the range of the local bioavailable signature (Figure 6b, SI-9 \& Tables S16-S17), and are consistent with a subsistence strategy based on immediately available local resources. Low levels of mobility are also supported by previous studies of femur midshaft morphology (Da-Gloria 2012). The aforementioned 

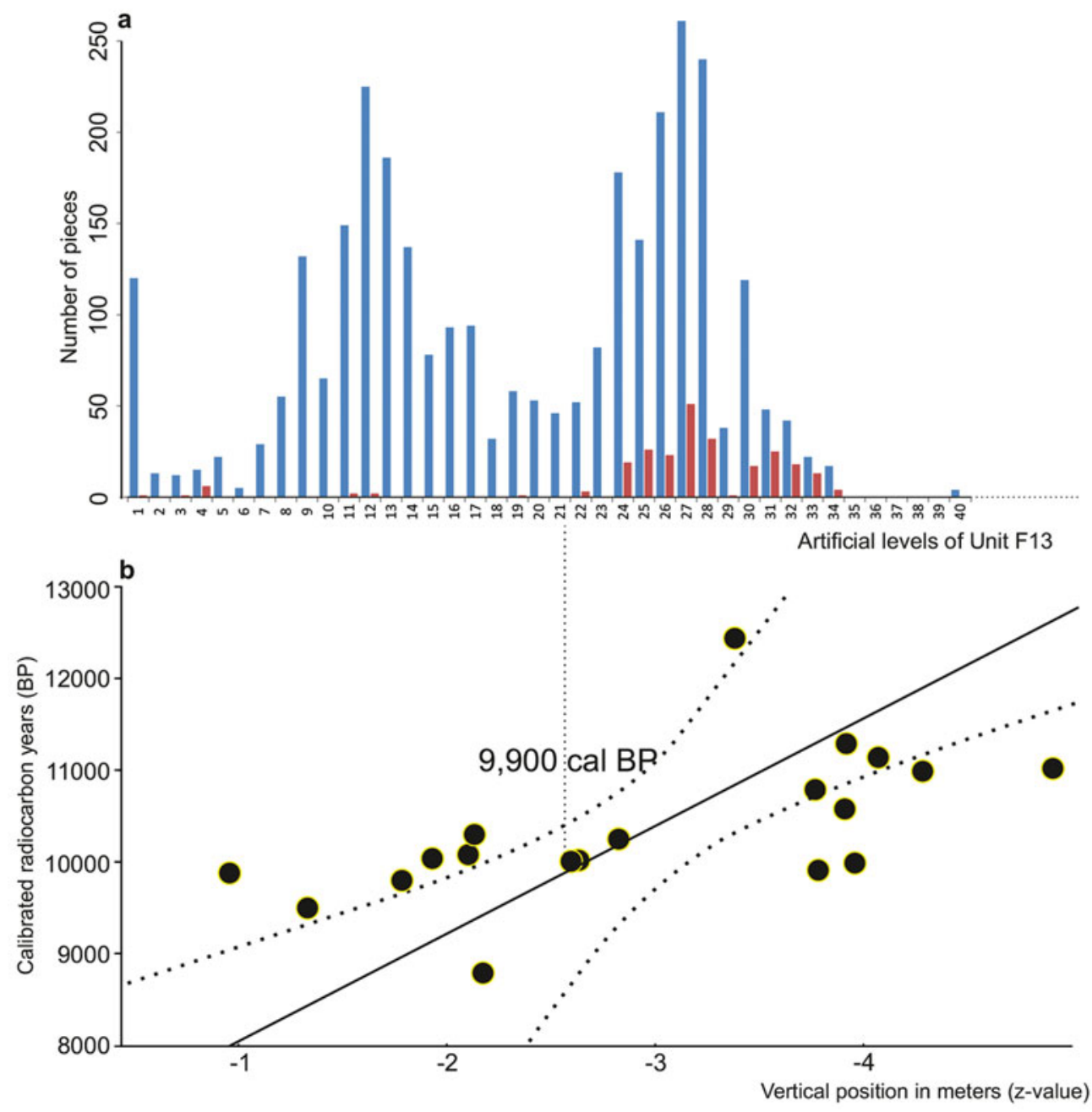

Figure 6. Chronological behaviour of lithic abundance and type of raw material in Lapa do Santo during the early Holocene: a) histogram of quartz (blue bars) and silexite (red bars) abundance; b) the event identified in the histogram is dated by comparing its vertical position (z-value) with the calibrated radiocarbon dates from charcoals (black disks) from unit F13 and the adjacent unit $G 13$ in the correspondent vertical position.

abandonment of allochthonous raw material for lithic production after $9.9 \pm 0.5 \mathrm{ky} \mathrm{cal} \mathrm{BP}$ could indicate the moment when this less-mobile mode of life began. Lapa do Santo is also known for its early Holocene low-relief rock art record, including a pictorial tradition that depicts phallic imagery.

Analysis of morphological affinities shows that individuals from Lapa do Santo share a typical Palaeoamerican cranial morphology with other groups of the Lagoa Santa region (Figure 7, SI-10 \& Tables S18-S19).

(C) Antiquity Publications Ltd, 2016 

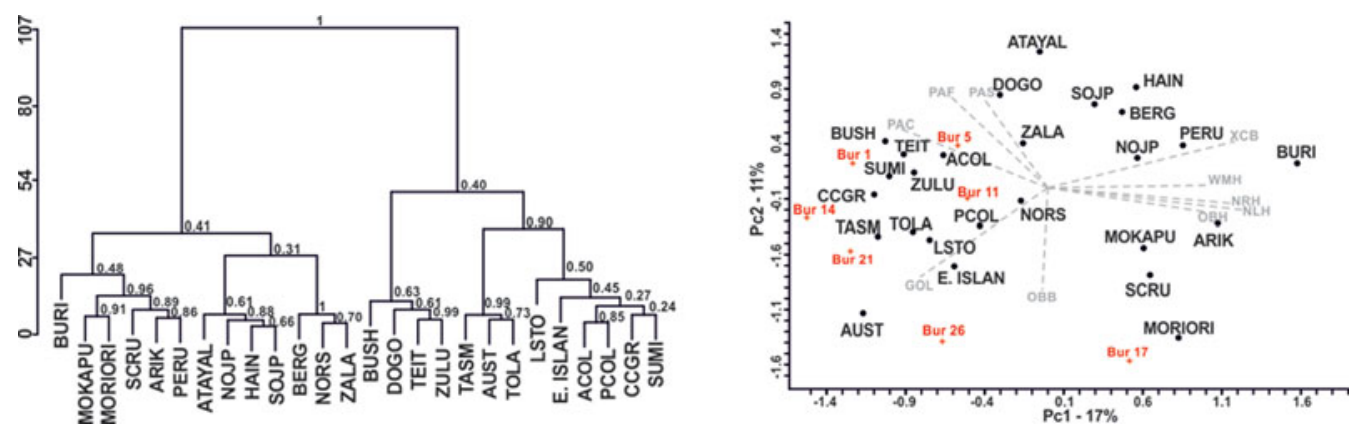

Figure 7. Morphological affinities of Lapa do Santo crania. See SI-15 for detailed legend.
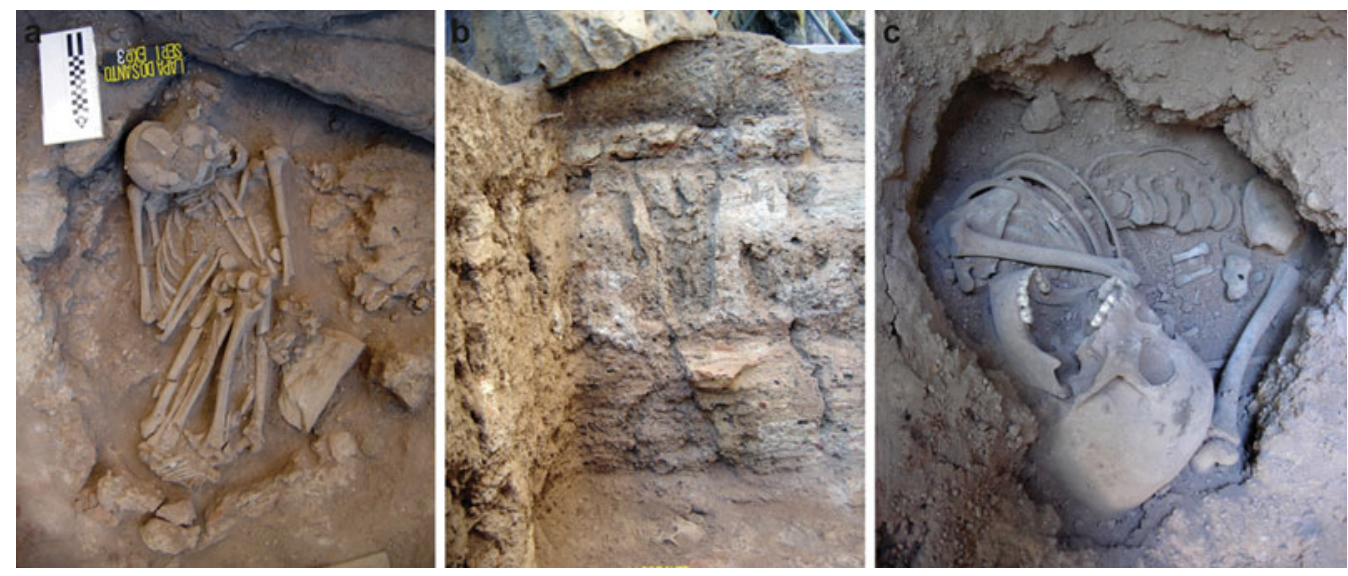

Figure 8. Lapa do Santo Mortuary Pattern 1. Fully articulated skeletons of single individuals. See SI-15 for detailed legend.

\section{Mortuary patterns}

The 26 human burials from Lapa do Santo were divided into six mortuary patterns based on chronology and shared features (see Table S20 and SI-11 for age and sex estimation). Lapa do Santo Mortuary Patterns (LSMP) 1, 2 and 3 are the focus of this paper. LSMP-1 is dated to $9.7-10.6 \mathrm{ky}$ cal BP and is characterised by two primary single burials in flexed position (Burials 1 and 27; Figure 8). LSMP-2 is dated to 9.4-9.6 ky cal BP and can be further subdivided into LSMP-2a (Burials 21 \& 26), LSMP-2b (Burials 9, 14, 17, 18 \& 23) and LSMP-2c (isolated bones).

LSMP-2a is characterised by fully articulated partial skeletons with cutting and chopping marks. In Burial 21, the midshafts of both tibiae and fibulae were chopped and removed while soft tissue was present (Figure 9a-c). Burial 26 is a decapitated head with the first six cervical vertebrae articulated in anatomical position (Strauss et al. 2015). The hyoid bone is missing and both amputated hands are laid over the face (Figure 9d). Scanning electron microscopy and confocal microscopy of the cut-marks (Figure 9e) show the presence of parallel micro-striations and a V-shaped transversal profile, indicating the use of stone flakes as the cutting agent (Figure $9 \mathrm{f}-\mathrm{g}$ ). The evidence shows that LSMP-2a involved the mutilation of fresh corpses. 

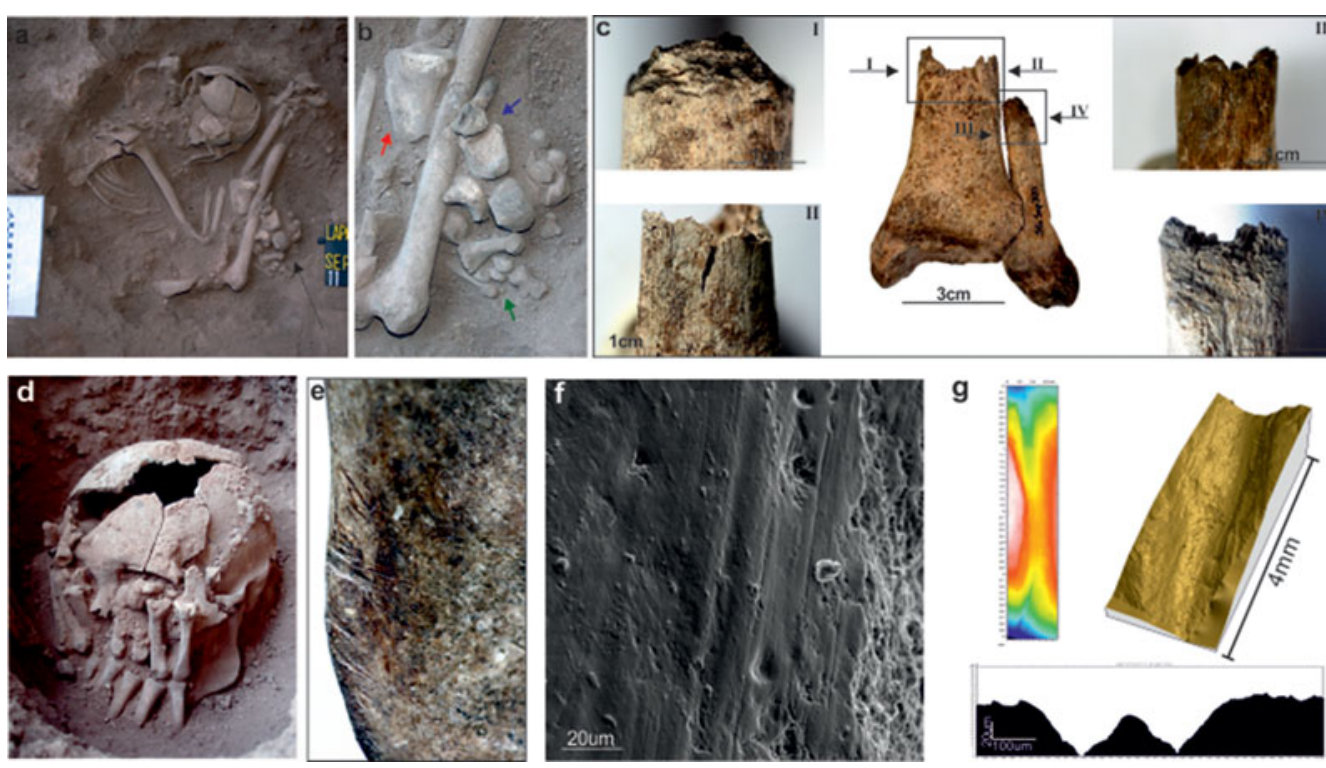

Figure 9. Lapa do Santo Mortuary Pattern 2a. a-c) Burial 21 from Lapa do Santo. Note that, although fully articulated, the midshafts of the lower legs were absent (black arrow) and the extremities chopped; d) Burial 26 from Lapa do Santo. The head was buried with amputated hands. Macro- and microscopic images of associated cut-marks are shown in details e-f. See SI-15 for detailed legend.

LSMP-2b is characterised by graves filled with the fully disarticulated bones of up to five individuals, with clear selection of particular anatomical parts. Some bones show evidence of exposure to fire, application of red pigment, defleshing, cutting, chopping and removal of teeth. Burials 14, 17 and 18 comprised a bundle of post-cranial bones from one or two individuals, deposited with the cranium and/or mandible of a different individual. Bundles of infant post-cranial bones were found next to adult crania (Burials 14 and 17; Figure 10ab), and bundles of adult post-cranial bones were found next to an infant cranium (Burial 18; Figure 10c). The long bones of the bundles had been chopped and segregated into 'extremities' (Figure 10d) and 'midshafts' (Figure 10e), and in some cases, the latter were further burned and chopped into smaller sections (Figure 10f). The calvaria of Burial 17 was used as a funerary receptacle (Figure $10 \mathrm{~g}$ ) and filled with chopped burnt bones (Figure 10f), some of which present defleshing cut-marks (Figure 10h). Black burn marks limited to the anterior portion of the external maxillary alveolar margin indicate exposure to fire while soft tissue was still present in the face (Figure 10i). The co-occurrence of chopped and defleshed bones with signs of burning of soft tissues suggests that LSMP-2 may have involved some form of ritual cannibalism.

In Burials 17 and 18, all teeth were intentionally removed (Figure 10j), and the coronoid processes of the mandible in Burial 18 were drilled (Figure 10k). Red pigment was abundantly applied to the bones of Burial 14 (Figure 10l) and Burial 18. Burial 23 was composed of a cranium calotte filled with 54 permanent and 30 deciduous teeth, some of which belonged to the skull of Burial 17. In Burial 9 an individual child skull was placed near the pelvis of an individual of similar age. The deciduous dentition was removed, and (C) Antiquity Publications Ltd, 2016 

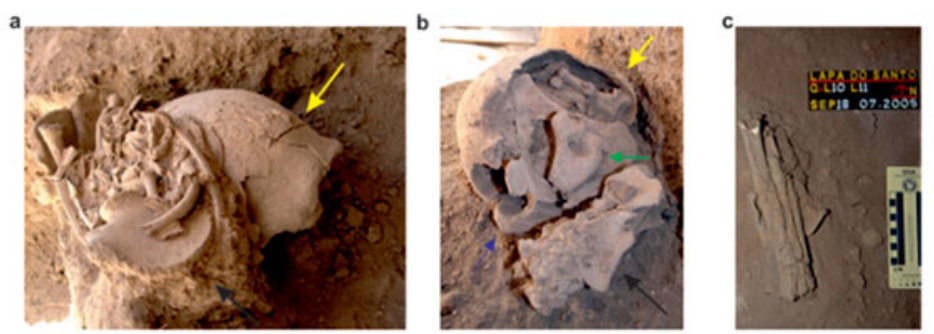

d
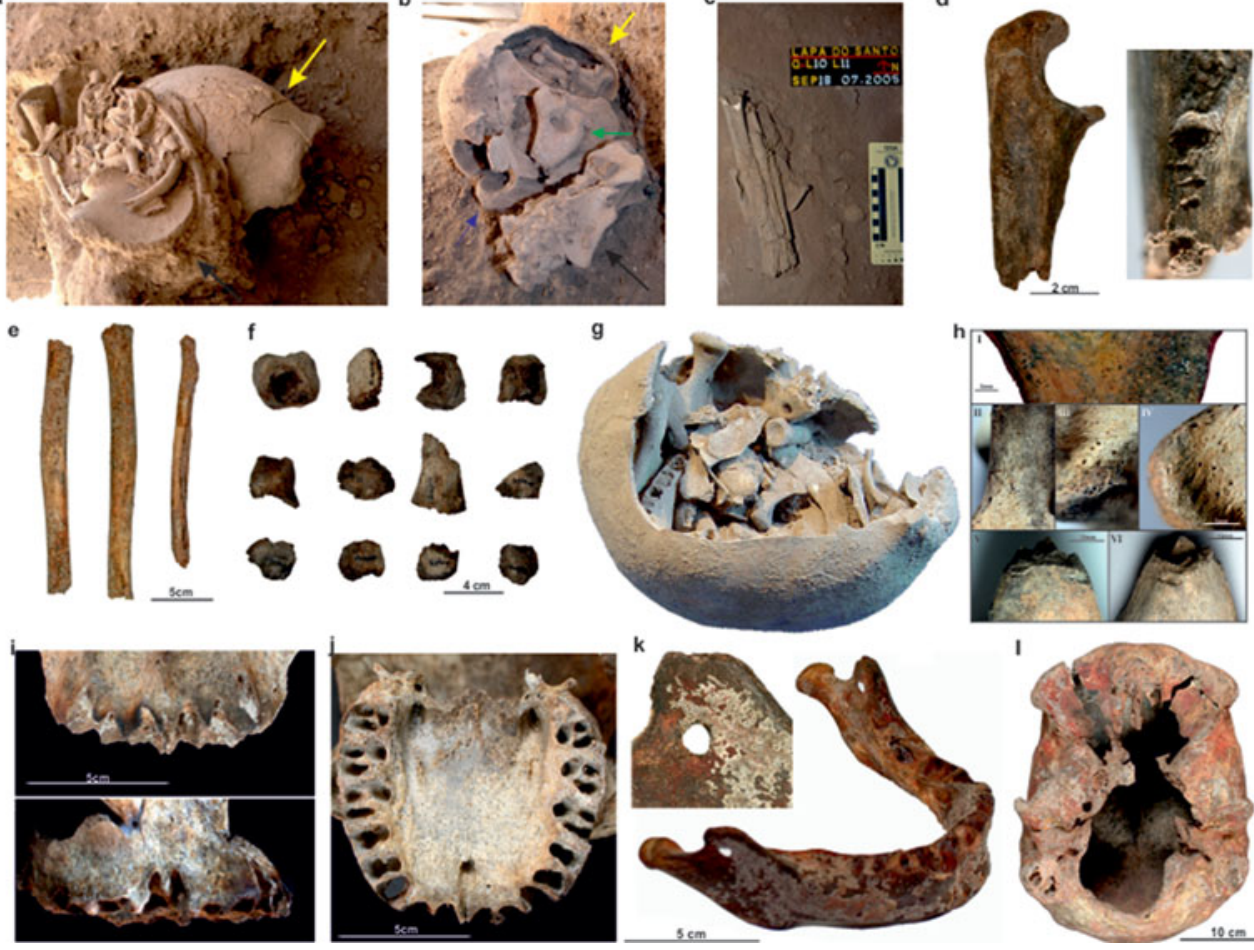

Figure 10. Lapa do Santo Mortuary Pattern 2b. a-c) Individualised crania next to a bundle of post-cranial bones; $d-f$ ) chopped human bones ( $f$ is also burnt); $g$ ) calvaria used as a funerary receptacle; h) defleshing marks on human bone; i) burning marks in the anterior alveoli margin; $j$ ) teeth avulsion; $k$ ) hole drilled in the coronoid processes; l) application of red ochre. See SI-15 for detailed legend.

an assemblage of human teeth and chopped midshafts (accession code: LSt-2253) were deposited next to Burial 9 (Figure S7). LSMP-2c is defined by isolated, burnt, chopped bones that were not part of any formal burial (Figure 11). In the case of the distal left femur (LSt-3083), the burn mark exclusively affected the area close to the chopped extremity of the bone (Figure 11a), a feature indicative of exposure to fire while flesh was still adhering to it (known as 'bratenspur' in the Germanic specialised literature; Kokabi et al. 1994; Wahl 1994). The same bone presents gnaw marks (Figure 11e-f), suggesting that it was subject to scavenging and was not immediately buried.

LSMP-3 is dated to $8.2-8.6 \mathrm{ky} \mathrm{cal} \mathrm{BP}$ and includes nine burials: $6,7,10,11,12,13$, 15,19 and 22 . The burials are characterised by shallow, circular pits completely filled with mostly disarticulated bones of single individuals of various ages and sexes (Figure 12a). Circular stone structures covered some of the burials, but also occur independently of them (Figure 12b). Anatomical selection was not observed and, with the exception of some small bones, most elements of the skeleton were present. The midshafts of long bones of adult individuals were, in some cases, intentionally broken in the central region before deposition (Figure 12c), resulting in butterfly fractures with impact points (Figure 12d). The burials belonging to LSMP-3 are very similar to each other, contrasting with the greater variability

(C) Antiquity Publications Ltd, 2016 


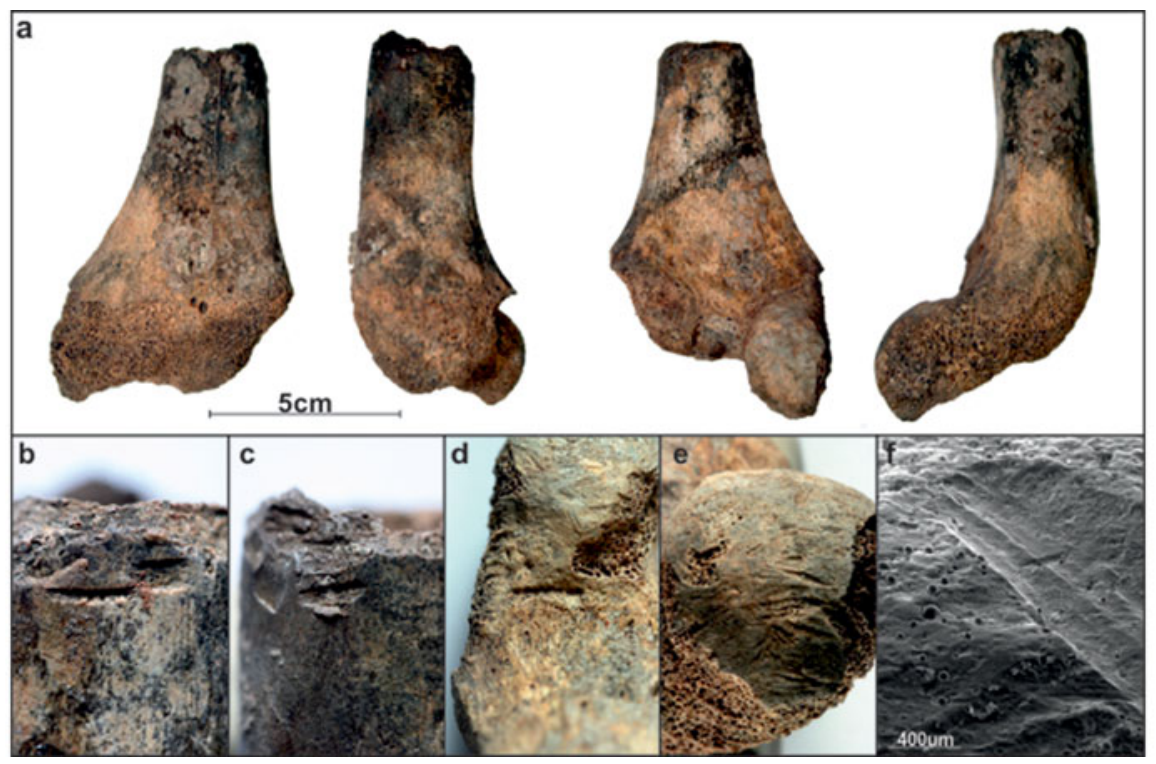

Figure 11. Lapa do Santo Mortuary Pattern 2c. Chopped, burnt and gnawed distal extremity of left femur (LSt-3083), found isolated from other human remains. See SI-15 for detailed legend.

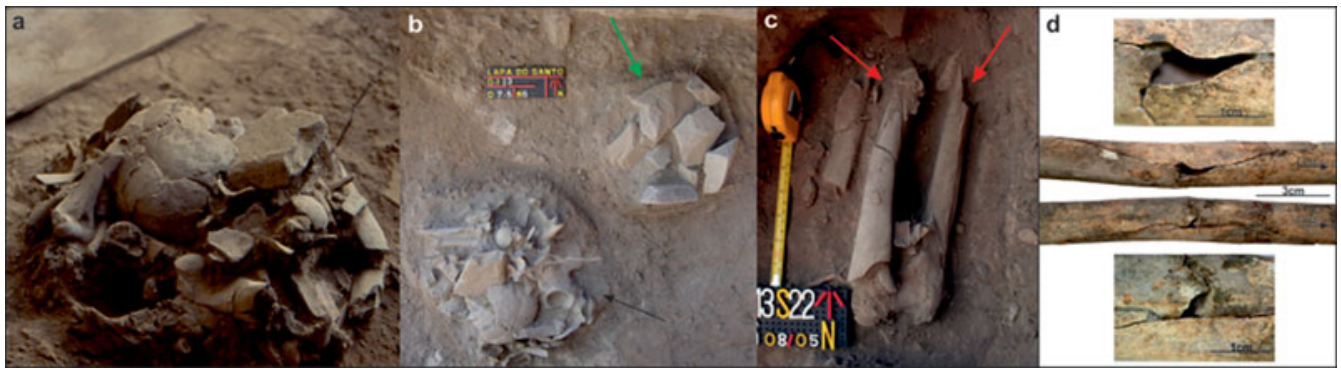

Figure 12. Lapa do Santo Mortuary Pattern 3. Circular pits completely filled with the non-articulated bones of a single individual, and long bones presenting peri-mortem fractures. See SI-15 for detailed legend.

observed within LSMP-2. Furthermore, characteristic elements of the latter, such as cutmarks, chop-marks, the absence of dentition, red pigment and burn marks are not present in the former.

\section{Discussion}

\section{Lapa do Santo mortuary record}

During the Archaic period in South America, burying the dead within the domestic space was a common practice. Accordingly, Lapa do Santo was not exclusively used as a burial site and cannot be classified as a formal cemetery (Pardoe 1988). The accumulation of burials there must be understood as a long-term process resulting from the association between formal prescriptions for treating the dead and the nature of Lapa do Santo as (C) Antiquity Publications Ltd, 2016 
a 'persistent place' (in the sense of Schlanger (1992)) that was repeatedly visited due to its unique features in the landscape. This rockshelter is better classified as an area intentionally maintained for burying the dead (in the sense of Littleton \& Allen 2007), rather than as a formal cemetery. Nevertheless, the funerary agents were following highly formal prescriptions in dealing with death, so Lapa do Santo presents a scenario where this occurs without the existence of formal cemeteries. Since non-articulated burials are rarely related to social organisation or economic demands, the Lapa do Santo mortuary record should be seen as a response to unique ideational and metaphysical concepts (e.g. Schroeder 2001).

More specifically, LSMP-2 can be interpreted as the result of a funerary ritual based on principles of secondarisation (Hertz 1907; Huntington \& Metcalf 1979), in which LSMP$2 \mathrm{a}$ represents the initial phase, LSMP-2b the final disposal of the remains and LSMP-2c the by-product of the dismemberment process. The careful organisation of bones and body parts in deliberate arrangements is compatible with an intermediate phase in which curation and public display were essential elements to enhance the visual communication of the ceremonies. This kind of ritual is traditionally understood as a mechanism to increase social cohesion during times of disruption.

The strict observance of such specific and technically demanding procedures suggests the existence of specialised funerary agents. In ancient societies, hard organic residues constituted a potent cultural resource, and the manipulation and organisation of bones and body parts were commonly used to reify cosmological principles (Brown 2010). In LSMP-2, this seems to have been centred on a 'dichotomic principle' that was expressed by pairs of oppositions among abstract categories such as 'adult' and 'sub-adult', 'cranium' and 'post-cranium', 'diaphysis' and 'extremities', and 'teeth' and 'empty alveoli'.

The organisation of disarticulated bones into meaningful arrangements or conceptual designs as observed in LSMP-2b probably mirrors key features of the cosmology of the groups involved, concerning the origin and organisation of their universe (Brown 2010: 32). We may never be able to precisely unveil these cosmological principles, but being able to visualise their reification in such detail is already a privilege not frequently granted to archaeologists studying the early Holocene of South America. Complex mortuary rituals such as those of LSMP-2 allow us to approximate the plotline of myths that give access to the cosmological world of these past societies (Brown 2010). It seems that the dualistic principle, long recognised as central in both the Andes (Rostworowski 1983) and the Amazon region (Maybury-Lewis 1979; Viveiros de Castro 1992) was already present among the earliest inhabitants of South America.

LSMP-3, on the other hand, is believed to result from the practice of 'delayed burial'. The body was allowed to decompose elsewhere until almost completely decayed. The bones were then brought to Lapa do Santo and deposited in a circular pit. Some adult long bones required breaking to ensure that the skeleton would fit inside the grave. LSMP-3 does not align well with available models relating secondary burials and mobility patterns in hunter-gatherers where secondary burials have been proposed to reflect deaths occurring away from the residential camp, e.g. during long-term hunting expeditions (e.g. Charles \& Buikstra 1983; Schroeder 2001). If this were the case at Lapa do Santo, the unusually high frequency of secondary burials in LSMP-3 (100\%) would require significant logistical

(C) Antiquity Publications Ltd, 2016 
organisation in which seasonal collectors explored vast territories and brought back the bones (or body parts) of the deceased. In LSMP-3, however, the secondary burials also include infants and females, suggesting that the delay of interment is not related to 'situational circumstances' but to formal mortuary prescriptions applied to the entire group (Schroeder 2001). One possible interpretation is that the delay was due to the intention of using the funerary rituals within rockshelters as special aggregation events at certain times.

\section{Diachronic changes to mortuary practices}

It has been traditionally assumed that all early Holocene burials from the Lagoa Santa region belonged to a single, highly homogeneous mortuary pattern. The findings from Lapa do Santo show that this is an incorrect assumption resulting from the lack of a proper chronology (O'Shea 1984) for the skeletons of the region. When the variety of burials is properly partitioned, it reveals a succession of short-term funerary patterns.

It has recently been argued, based on the analysis of stone tools, that some prehistoric forager groups in South America were remarkably static through time. This would be compatible with the existence of a "novelty-avoidance" mechanism among those groups (Okumura \& Araujo 2014: 59). In this regard, Lapa do Santo is enlightening. It is only when the Lapa do Santo mortuary record is considered that the dynamic nature of these groups, which were in a state of constant transformation over a period of centuries, is perceived (O'Shea 1984). At this point, however, it is not possible to assert whether these changes were the result of internal transformations in the social organisation of these groups, the arrival of newcomers, or even whether they reflect a process of cultural drift.

Other sites in South America such as OGSE-80, Cuchipuy, Arroyo Seco 2 and Justino present a similar pattern, with one locality used as a mortuary site for millennia by different and successive groups. In other cases, however, the same mortuary pattern is observed for long periods, e.g. Baño Nuevo-1, Paloma and the Chinchorro. This chronological variability in behaviour in the South American archaeological record helps to explain why the old debate around the temporal stability of the mortuary rituals has never been adequately settled (Kroeber 1927; O’Shea 1984).

\section{Lapa do Santo in the regional landscape}

(Please see SI for a complete list of primary references concerning the sites mentioned in the text.)

After more than 170 years of archaeological research, with hundreds of exhumed early Holocene skeletons, a consensus had been reached in the literature that the mortuary rituals of Lagoa Santa during that period were simple, homogeneous and stable through time. Based on this traditional view, one could postulate that Lapa do Santo was a regional centre where particularly elaborate funerals were reserved for special individuals, with other sites in the region used for more common burials.

(C) Antiquity Publications Ltd, 2016 
When the sparse descriptions of the burials made by previous scholars were scrutinised, it became apparent that they were incorrect. In the Cerca Grande complex, only primary single burials were originally reported, but subsequent researchers studying the collection spotted several cut-marks in the human bones and reported burials with multiple individuals (Da-Gloria 2012). Similarly, it is likely that the isolated skull with a huge fracture exhumed from Lapa das Limeiras (Walter 1958) and the 'molehills' composed of the skull of a child and the skeleton of an elderly woman found in the second chamber of Lapa da Samambaia are analogous to the individual skulls described here for LSMP-2b (i.e. Burials 9, 14, 17, 18 \& 23). At the site of Confins, 'pipes' crafted from a burnt human femur were reported (Walter 1958). From the available pictures (Walter 1958: 93), it is clear that these pipes are identical to the isolated burnt bones from LSMP-2c. Corroborating this interpretation, a total of 23 chopped adult bones identical to those of LSMP-2 were identified in the Harold Walter collection (observed by author AS). For Confins, Cerca Grande and the Harold Walter collection, this association is further supported by the existence of directly dated bones that are pericontemporaneous with LSMP-2. This supports the notion that the pattern described for LSMP-2 was relatively widespread in Lagoa Santa and not restricted to Lapa do Santo at 9.4-9.6 ky cal BP.

In addition to these cases of chopped or isolated bones, descriptions of highly fragmented skeletons within a small grave covered by a layer of limestone blocks are also known from the literature, e.g. Lapa da Mãe Rosa, Lapa da Limeira, Terraço do Sumidouro, Cerca Grande 5 and Cerca Grande 6 (Walter 1958). It was assumed that such high levels of fragmentation were caused by the weight of the limestone blocks. In light of the findings from Lapa do Santo it may be that in many sites these 'highly fragmented' burials were analogous to LSMP-3. In at least some of these sites, direct dating of bones falls roughly in the chronological range of LSMP-3. Future studies looking for peri-mortem fractures among skeletons from Lagoa Santa will confirm whether this association is indeed correct.

\section{Continental perspective of Lapa do Santo}

Early Holocene funerary rituals focusing on manipulating and transforming the human body are better characterised in the Andean region of South America where more sites are known (Santoro et al. 2005). For this reason, the manipulation of the body as part of funerary rituals was sometimes assumed to be an Andean phenomenon preceding the rituals arising later with the emergence of complex societies. Lapa do Santo, however, expands the geographic range of such practices to the Brazilian lowlands and suggests a more complex scenario for its development within the continent.

Compared to nearby sites, Lagoa Santa constituted a coherent and localised cultural unity. Burials at Santana do Riacho (around $50 \mathrm{~km}$ away) are estimated to date to around 9.0 ky BP (non-calibrated) — contemporaneous with LSMP-1 and slightly older than LSMP-2. They are characterised by fully articulated skeletons in flexed positions, but the comparison is contested, with some authors arguing for some sort of body manipulation at Santana do Riacho (Lavallée 1995), while others disagree (Prous 1992/1993).

(C) Antiquity Publications Ltd, 2016 
Farther away, the sites of Capelinha and Toca dos Coqueiros have burials roughly contemporaneous with LSMP-1 (although the latter is not directly dated). In both cases, fully articulated, flexed skeletons were found in association with projectile points. In Justino, four articulated burials and one 'secondary burial' were associated with charcoal dated to 8.9 ky BP (non-calibrated). These sites are too far from each other and from Lagoa Santa to allow any direct connection to be postulated. Nevertheless, in this period, rock art from sites just as distant already shared very clear stylistic elements, so the similarities between mortuary practices may reflect a shared cultural ancestry. Although the limited available evidence must be interpreted with caution, it seems that during the early Holocene, Lagoa Santa was the only place where funerary rituals such as those represented by LSMP-2 and LSMP-3 were taking place in Brazil.

After $8.0 \mathrm{ky}$ BP, other eastern South American sites do show evidence of rituals involving body manipulation and reduction. In Burial 1 from Lapa do Malhador, the right arm of an entirely articulated skeleton had been amputated, leaving a profusion of cut-marks on the bones. This burial is assumed to be middle Holocene in age and therefore younger than LSMP-2, but in the absence of a direct date, an earlier date cannot be ruled out. Loca do Suin has two burials directly dated to 7.4 and $7.5 \mathrm{ky} \mathrm{BP}$, including a case of cremation and the presence of multiple individuals.

The presence of mortuary rituals focusing on reducing the body at sites thousands of kilometres from each other shows that this was a common practice across the continent from the early Holocene, e.g. Arroyo Seco 2, Pampa de los Fóssiles, Lauricocha, Huchichocana Cave, La Chimba and La Fundición, Baño Nuevo and Tequendama (see Santoro et al. 2005 for a comprehensive review). More specifically, LSMP-2 has similarities with the mortuary record of sites in the Sabana de Bogotá region of Colombia, especially Aguazuque. Here, the funerary rituals are also characterised by a strong selection and re-allocation of different parts of the human body, including the separation of skulls and the sectioning of long-bones to separate the diaphysis from its extremities. It is hard to know to what extent such similarities are random and to what extent they reflect a common cultural background. Craniometric studies point to a very close genetic relationship between the Lagoa Santa and Sabana de Bogotá populations, suggesting that shared ancestry is at least a possibility.

\section{Conclusion}

Lagoa Santa is the only location in Brazil, and one of the few in the entire continent, where well-preserved, securely dated and abundant human burials—as well as rock artfrom the early Holocene occur in association with more ubiquitous archaeological remains such as stone tools, animal bones and combustion structures. Research has previously focused on the co-existence of humans and megafauna and the distinct cranial morphology compared to Native Americans from across the American continents. Other aspects of the archaeological record were neglected, resulting in a limited, biased view, characterising the groups inhabiting the region during this period as simple and static through time. This paper is part of a broader effort to promote a paradigm shift within archaeological 
research in Lagoa Santa, emphasising the reconstruction of human behaviour and its diversity among past hunter-gatherers (Araujo et al. 2012; Da-Gloria 2012; Strauss et al. 2015).

Between 12.7-11.7 ky cal BP and 8.3-8.0 ky cal BP, the Lapa do Santo region was occupied by early Archaic generalised foragers. Lithic technology, zooarchaeology and multi-isotopic analyses indicate that groups of hunter-gatherers with low mobility and a subsistence strategy focused on gathering plant foods and hunting small and mid-sized animals. This efficient technology and subsistence strategy endured for more than four millennia. The use of Lapa do Santo for interment started with primary burials between 10.3 and $10.6 \mathrm{ky}$ cal BP. Between 9.4 and $9.6 \mathrm{ky} \mathrm{cal} \mathrm{BP}$, the reduction of the body-by mutilation, defleshing, tooth removal, exposure to fire and possibly cannibalism-followed by the secondary burial of the remains according to strict rules, became a central element in the treatment of the dead. In the absence of monumental architecture or grave goods, parts of fresh corpses were used to elaborate rituals: evidence that this practice was not restricted to the Andean region at this time. Between 8.2 and $8.6 \mathrm{ky} \mathrm{cal} \mathrm{BP}$, another change occurred when pits were instead filled with the disarticulated bones of a single individual, without signs of body manipulation.

The stability of lithic types in Lapa do Santo and elsewhere in the region were once considered to indicate a low degree of cultural diversity over time. This view was epitomised by the term 'People of Luzia', coined to include all groups inhabiting the region during the early Holocene. The shared use of a specific techno-functional strategy might not, however, be the best proxy of cultural identity. In Lapa do Santo, the mortuary practices underwent transformation within relatively short periods of time, showing how a purely technologically oriented interpretation of the past can obliterate the elevated cultural diversity that was already established in the region by the beginning of the Holocene. It is proposed, therefore, that the traditional notion of a single 'People of Luzia' should be abandoned. Instead, during the early Holocene, Lagoa Santa was inhabited by 'human groups' that were culturally diverse and, tentatively, indicative of the early occurrence of regional processes of ethnogenesis.

These groups were also traditionally depicted as presenting simple and expedient funerary rituals. The evidence from Lapa do Santo and the critical reappraisal of the literature presented here show, however, that they elaborated their funerary rituals through the manipulation and organisation of body parts. In a regional perspective, Lagoa Santa is unique in presenting these elaborated rituals, and there is no other location in Brazil where similar practices can be found for this time frame. More broadly, similar instances are known both along the Andes and in the Pampas.

The scarcity of Brazilian sites containing early Holocene human skeletons prevents any further attempt to identify significant regional patterns, so it is crucial to identify and excavate new sites. The general paucity of skeletal remains has been attributed to acidic soils precluding their preservation. Although this must be taken into account, there are other important factors, not least the vast scale of the region and, most importantly, the relatively recent beginnings of systematic research. If this gap is to be filled over coming decades, research in the region must expand and intensify.

(C) Antiquity Publications Ltd, 2016 


\section{Acknowledgements}

We thank all participants in the Lapa do Santo excavations: José Hein for supporting research on his farm; Rogério Tavares de Oliveira and the IEF for providing us with accommodation and logistics; the Brazilian authorities (IPHAN and IBAMA) for swiftly providing necessary documentation; Nadia Scott, Célia Boyadjian, Stephanie Schnorr and Alejandra Ortiz for comments on the manuscript; João Bárbara Filho for logistic assistance in the field; and the cities of Matozinhos and Pedro Leopoldo for facilitating our work. Eduardo Goés Neves and other reviewers made important contributions to the manuscript. We would like to thank FAPESP, CNPq, the Alexander Von Humboldt Foundation, Ciências Sem Fronteiras, Generalitat Valenciana (VALi+d APOSTD/2014/123), Eberhard-Karls-Universität Tübingen and the Max Planck Society for financial support.

\section{Supplementary material}

To view supplementary material for this article, please visit http://dx.doi.org/10.15184/aqy. 2016.220

\section{References}

(See SI for extended reference list.)

Araujo, A.G.M., W.A. Neves \& R. Kipnis. 2012. Lagoa Santa revisited: an overview of the chronology, subsistence, and material culture of Paleoindian sites in eastern central Brazil. Latin American Antiquity 23: 533-50. http://dx.doi.org/10.7183/1045-6635.23.4.533

Bissaro, M.C. JR. 2008. Tafonomia como ferramenta zooarqueológica de interpretação: viés de representatividade óssea em sítios arqueológicos, paleontológico e etnográfico. Unpublished MA dissertation, Universidade de São Paulo.

BoËda, E., I. Clemente-Conte, M. Fontugne, C. Lahaye, M. Pino, G.D. Felice, N. Guidon, S. Hoeltz, A. Lourdeau, M. Pagli, A.-M. Pessis, S. Viana, A. Da Costa \& E. Douville. 2014. A new late Pleistocene archaeological sequence in South America: the Vale da Pedra Furada (Piauí, Brazil). Antiquity 88: 927-41. http://dx.doi.org/10.1017/S0003598X00050845

BROWN, J. 2010. Cosmological layouts of secondary burial as political instruments, in L.P. Sullivan \& R.C. Mainfort (ed.) Mississippian mortuary practices: beyond hierarchy and the representationist perspective: 30-53. Gainesville: University Press of Florida.

Bueno, L., A.S. Dias \& J. Steele. 2013. The Late Pleistocene archaeological record in Brazil: a geo-referenced database. Quaternary International 301: 74-93. http://dx.doi.org/10.1016/j.quaint.2013.03.042

Charles, D.K. \& J.E. Buikstra. 1983. Archaic mortuary sites in the central Mississippi drainage: distribution, structure, and behavioral implications, in J.L. Phillips \& J.A. Brown (ed.) Archaic hunters and gatherers in the American Midwest: 117-44. New York: Academic.
DA-GLORIA, P. 2012. Health and lifestyle in the Paleoamericans: early Holocene biocultural adaptation at Lagoa Santa, central Brazil. Unpublished PhD dissertation, The Ohio State University.

Goldstein, L.G. 2000. Mississippian ritual secondary disposal, in S.R. Ahler (ed.) Mounds, Modoc, and Mesoamerica: papers in honor of Melvin L. Fowler: 193-205. Springfield: Illinois State Museum.

Hertz, R. 1907. Contribution à une étude sur la représentation collective de la mort. Année sociologique 10: 48-137.

Huntington, R. \& P. Metcalf. 1979. Celebrations of death: the anthropology of mortuary ritual. Cambridge: Cambridge University Press.

Kokabi, M., G. Amberger \& J. Wahl. 1994. Die knochenfunde aus der Villa rustica von Bondorf. Die Villa rustica von Bondorf 51: 285-335.

Kroeber, A. 1927. Disposal of the dead. American Anthropologist 29: 308-15. http://dx.doi.org/10.1525/aa.1927.29.3.02a00090

LaVAlLÉE, D. 1995. The first South Americans: the peopling of a continent from the earliest evidence to high culture. Salt Lake City: University of Utah Press.

Littleton, J. \& H. Allen. 2007. Hunter-gatherer burials and the creation of persistent places in southeastern Australia. Journal of Anthropological Archaeology 26: 283-98. http://dx.doi.org/ 10.1016/j.jaa.2006.11.004

Maybury-Lewis, D. 1979. Dialectical societies: the Gê and Bororo of central Brazil. Cambridge (MA): Harvard University Press. http: //dx.doi.org/10.4159/harvard.9780674180727

O'SHEA, J. 1984. Mortuary variability: an archaeological investigation. New York: Academic. 


\section{Early Holocene ritual complexity in South America}

Okumura, M. \& A.G.M. Araujo. 2014. Long-term cultural stability in hunter-gatherers. Journal of Archaeological Science 45: 59-71. http://dx.doi.org/10.1016/j.jas.2014.02.009

Pardoe, C. 1988. Cemetery as symbol. Archaeology in Oceania 16: 173-78.

Prous, A. 1992/1993. As estruturas aparentes: os sepultamentos do Grande Abrigo de Santana do Riacho. Os sepultamentos da escavação $\mathrm{N}^{\circ} 1$. Arquivos do Museu de História Natural 13/14: 21-92.

Pugliese, F. 2007. Os líticos de Lagoa Santa. Unpublished MA dissertation, Universidade de São Paulo.

Rostworowski, M. 1983. Estructuras andinas del poder. Ideologia religiosa y política. Lima: Instituto de Estudios Peruanos.

Santoro, C.M., V.G. Standen, B.T. Arriaza \& T.D. Dillehay. 2005. Archaic funerary pattern or postdepositional alteration? The Patapatane burial in the highlands of south central Andes. Latin American Antiquity 16: 329-46. http://dx.doi.org/10.2307/30042497

Schlanger, S.H. 1992. Recognizing persistent places in Anasazi settlement systems, in J. Rossignol \& L. Wandsnider (ed.) Space, time, and archaeological landscapes: 91-112. New York: Plenum.
Schroeder, S. 2001. Secondary disposal of the dead: cross-cultural codes. World Cultures 12: 77-93.

Sofaer, J.R. 2006. The body as material culture: a theoretical osteoarchaeology. Cambridge: Cambridge University Press. http://dx.doi.org/10.1017/CBO9780511816666

Strauss, A.M., R. Oliveira, D.V. Bernardo, D.C. Salazar-García, S. Talamo, K. Jaouen, M. Hubbe, S. Black, C. Wilkinson, M.P. Richards, A.G.M. Araujo, R. Kipnis \& W.A. Neves. 2015. The oldest case of decapitation in the New World (Lapa do Santo, east-central Brazil). PLoS ONE 10: e0137456. http://dx.doi.org/10.1371/journal.pone.0137456

Villagran, X., A.M. Strauss, C. Miller, B. Ligouis \& R. Oliveira. In press. Buried in the ashes: formation processes of an early South American site (Lapa do Santo, Brazil). Journal of Archaeological Science.

Viveiros de Castro, E. 1992. From the enemy's point of view. Chicago (IL): University of Chicago Press.

WAHL, J. 1994. Manipuliert menschenknochen aus Baden-Württemberg. Archäologische Information aus Baden-Württemberg 27: 129-40.

Walter, H.V. 1958. Arqueologia da região de Lagoa Santa. SEDEGRA, Rio de Janeiro. Rio de Janeiro: SEDEGRA.

Received: 18 August 2015; Accepted: 30 November 2015; Revised: 13 May 2016

(C) Antiquity Publications Ltd, 2016 